\title{
Degree of Adaptation to International Financial Reporting Standards: The Case of Turkey
}

\author{
Asst. Prof. Birsel Sabuncu \\ Pamukkale University
}

Doi: 10.19044/esj.2017.c1p20 URL:http://dx.doi.org/10.19044/esj.2017.c1p20

\begin{abstract}
With International Financial Reporting Standards (IFRS) a contribution is made to create a common language between the countries in accounting science and to constitute accounting provisions. Our country has not stayed away from this common language and currently, the studies on accounting science are underway. Public Oversight Accounting and Auditing Standards Authority have the International Financial Reporting Standards (IFRS) Turkish Accounting Standards translated into Turkish and published such as Turkish Accounting Standards /Turkish Financial Reporting Standards (TAS/TFRS) are as published. These are the Turkish translation of International Accounting/ Financial Reporting Standards. Now, in our country, a binary system is still used as Uniform Accounting System as well as TAS/TFRS are in ongoing process. There are different approaches towards the economy in terms of the standards and the Uniform Chart of Accounts and it is required to improve the current system and harmonize the Uniform Chart of Accounts with the standards.
\end{abstract}

Keywords: Turkish Accounting Standards/Turkish Financial Reporting Standards (TAS/TFRS), International Financial Reporting Standards (IFRS), Uniform Accounting System

\section{Introduction}

In a globalizing World, there is a requirement for countries to use a common business language regarding the accounting science. This process of convergence has started and needed among the accounting systems of the participating countries.

Through the Norwalk Agreement, that was signed between the International Accounting Standards Board (IASB) and Financial Accounting Standards Board (FASB), a change began in the World through the Conformity Process of the Standards and the International Financial Reporting Standards (IFRS) have begun to be used. Since Accounting is a social science 
the culture that it is included is quite functional in terms of affecting the accounting. Regarding the conformity of the countries to the International Financial Reporting Standards (IFRS), the cultural, political and economical reasons have been effective.

In Turkey, Public Oversight, Accounting and Auditing Standards Authority (POAASA), have been continuing its activities in respect of the Understanding and Implementing of Standards. Current International Financial Reporting Standards (IFRS) are not compatible with the Chart of Accounts which are in operation is needed by the Turkish Accounting Standards / Turkish Financial Reporting Standards (TAS/TFRS) which are used in Turkey. The accounts which are needed by IFRS do not exist in the Uniform Accounting Plan that is in operation in Turkey. Regarding the Uniform Accounting Plan, instead of making the business enterprises who are subject to report according to the standards free from the obligations; according to the needs, the actualisation of the completion of the harmonization process would be more easy by changing some account names and their positions within the Uniform Accounting Plan. Currently in Turkey, since both the Uniform Accounting Plan and the TAS/TFRS are in operation, a dual system is continuing at present. There are discrepancies regarding the approach of the Standards and the Uniform Accounting Plan to economic events. In the current system, there is a need for improvement and the harmonization of the Uniform Accounting Plan to the Standards.

\section{International Financial Reporting Standards (IFRS) in the World and its Harmonisation Process}

Regarding the Accounting the international harmonization has arisen due to the decreasing discrepancies between the Financial Reporting Implementation among the countries, the Comparability of the Financial Reporting, the need for the accounting standards which were accepted among all the countries (Hoyle vd., 2004: 537).

In Accounting Standards, there are a lot of factors that are required to provide the international harmonization and constitute the International Accounting Standards (Güney vd., 2012: 121):

- Internationalising of the capital markets,

- Increasing the number of the multinational companies,

- Increasing the efficiency of the independent auditing firms,

- Goals for constituting economic unions,

- Development of international regulations.

In accounting, the major organizations who studies for international harmonization; United Nations (UN), Organisation for Economic Cooperation and Development (OECD), International Organization of Securities 
Commissions (IOSCO), International Accounting Standards Board (IASB) and European Union (EU) (Parlakkaya, 2004: 122).

In 1966 the USA, Canada, and England established the Accounting International Study Group in order to analysis the accounting discrepancies between them. In 1973 it gave place to International Accounting Standards Committee (IASC) that was established by the participation of the USA, UK, Holland, Germany, Japan, Mexico, Southern Ireland, Canada and Australia. The purpose of IASC is to constitute the basic accounting standards which can be implemented all over the World (Fritz and Lamle, 2003: 41).

Until 2000 the committee so-called International Accounting Standards Committee (IASC), was named as International Accounting Standards Board (IASB) within the frame of the restructuring studies. Although the standards that were being issued by the committee were bearing the name of International Accounting Standards (IAS) until 2000, they have taken the name of International Financial Reporting Standards (IFRS) after 2000. The Norwalk Agreement was signed on September 18, 2002, in order to study the removal of the discrepancies between the IAS/IFRS and American Generally Accepted Accounting Principles (US-GAAP) (Gücenme Gençoğlu vd., 2013: 19).

At the joint meeting that FASB and IASB carried out in the USA who started to work together in 2002 signed an agreement that includes the commitments for improving the high-quality and compatible accounting standards to be used in Financial Reporting. (Kaya, 2003: 11).

In 2002 the EU declared that beginning from January 2005 the implementation of IFRS is an obligation for companies which are in the securities exchanges of the member governments. Accordingly, beginning from the year 2005, 8000 big European companies have to submit their financial reports according to the IFRS (Aysan, 2008: 48).

Regarding Asian countries, the accounting system was changed and new regulations were issued particularly as a result of the settlement of Shanghai and Shenzen stock markets in China at the early 90's. In 1998 Chinese Accounting Standards were started using the IFRS as a model and beginning from 2007 stock market companies had started to implement it (Chen vd., 2002: 184).

A lot of countries in the World have completed or about to complete their IFRS transformation. European Union Member Countries, South Africa, Australia, Hong Kong, Singapore, Malaysia, Indonesia, and Thailand are among these. The transition process for IFRS is continuing in varied steps in Romania, Croatia, Greece, Macedonia, Slovenia, Bulgaria, and Albania. 


\section{The Harmonization Process of International Financial Reporting Standards (IFRS) in Turkey}

In Turkey, the accounting cases are recorded by taking the General Communique on Accounting System Application which is the system in operation for a long time that was issued by Ministry of Finance on 26.12.1992, as the basis, and the Accounting is being carried out by taking the Uniform Accounting Plan that provides the standardization during the recognition, as the basis. In regard to accounting, the legal framework has an obligation for follow-up is being regulated by Tax Procedure Law, the accounting system that is based on the Uniform Chart of Accounts, and Turkish Commercial Code. The implementation of the Uniform Chart of Accounts has been applied for a long time both in the recognition of the cases and for the completion of the process of the financial reporting. The harmonization process to the existing system is continuing by coming into force through the International Financial Reporting Standards.

By the European Union Membership Process a need for the accounting standards that are compatible with all the markets arose for Turkey who had previously been affected by the German and French accounting systems because of its economic relationships. Due to this, the International Accounting Standards have become a current issue.

The first study in Turkey was started by the establishment of the Turkish Accounting Specialists Association (TASA) and the association has provided the publication of the translation of the International Accounting Standards into Turkish. Besides TASA has published the accepted 31 international accounting standards all together as a book (Parlakkaya, 2004: 130).

Turkish Accounting Standards/Turkish Reporting Standards (TAS/TRS) have the characteristics of a translation of the International Accounting Standards/International Financial Reporting Standards (IAS/IFRS). Along with the Norwalk Agreement that was signed in 2002 between International Accounting Standards Board (IASB) and Financial Accounting Standards Board (FASB), these studies for harmonizing the standards were begun.

The activity of TASA ended and 19 accounting standards which are compatible with the IFRS were issued by the newly-established Turkish Accounting and Auditing Standards Board (TAASB).

The activity of TAASB ended and the Turkish Accounting Standards Board (TASB) was founded in 2002 and has undertaken all of the activities of TAASB. By TASB 6 Turkish Financial Reporting Standards (TFRS) and 41 Turkish Accounting Standards (TAS) that are compatible with IFRS have been issued. 
The Turkish Accounting Standards Board (TASB) has translated all of the IFRS into Turkish and has declared them as Turkish Financial Reporting Standards (TFRS). By mid-2008 the process of harmonization to the IFRSs was completed. However, since TASB has been authorized as the only authority regarding the observation, implementation, and interpretation of Uniform Accounting Standards, Republic of Turkey Central Bank and Ministry of Finance have been structured according to the IFRSs (Aysan, 2008: 48).

In 2011, the duties and authorities of TASB have been transferred to the Public Oversight, Accounting and Auditing Standards Authority (POAASA). The studies regarding the standards that are compatible with the IFRS are being carried out by POAASA. In time, some standards were abolished, some of them were combined and assignments were done regarding their new numbers. By IFRS Code new numbers have been given to the newly formed standards.

As a result of the studies done in the direction of harmonization, purpose, and rudiments with IFRS in Turkey, current Accounting Standards, and Financial Reporting Standards that were issued regarding the implementation of the Turkish (TAS/TFRS) of IFRS until today in Turkey are as follows (http://kgk.gov.tr):

TAS 1 Presentation of Financial Statements

TAS 2 Inventories

TAS 7 Statement of Cash Flow

TAS 8 Accounting Policies, Changes in Accounting Estimates and Errors

TAS 10 Events after the Reporting Period

IAS 12 Income Taxes

TAS 16 Property, Plant, and Equipment

TAS 19 Employee Benefits

TAS 20 Accounting for Government Grants and Disclosure of Government Assistance

TAS 21 The Effects of Changes in Foreign Exchange Rates

TAS 23 Borrowing Costs

TAS 24 Related Party Disclosure

TAS 29 Financial Reporting in Hyperinflationary Economies

TAS 26 Accounting and Reporting by Retirement Benefit Plans

TAS 27 Separate Financial Statements

TAS 28 Investments in Associates and Joint Ventures

TAS 29 Financial Reporting in Hyperinflationary Economies

TAS 32 Financial Instruments: Presentation

TAS 33 Earnings per Share

TAS 34 Interim Financial Reporting 
TAS 36 Impairment of Assets

TAS 37 Provisions, Contingent Liabilities, and Contingent Assets

TAS 38 Intangible Assets

TAS 39 Financial Instruments: Recognition and Measurement

TAS 40 Investment Property

TAS 41 Agriculture

TFRS 1 First-time Adoption of International Financial Reporting Standards

TFRS 2 Share-based Payment

TFRS 3 Business Combinations

TFRS 4 Insurance Contracts

TFRS 5 Non-current Assets Held for Sale and Discontinued Operations

TFRS 6 Exploration for and Evaluation of Mineral Resources

TIFRS 7 Financial Instruments: Disclosures

TFRS 8 Operating Segments

TFRS 9 Financial Instruments

TFRS 10 Consolidated Financial Statements

TFRS 11 Joint Arrangements

TFRS 12 Disclosure of Interest in Other Entities

TFRS 13 Fair Value Measurement

TFRS 14 Regulatory Deferral Accounts

TFRS 15 Revenue from Contracts with Customers

In Turkey, only the "IFRS 16 Leases" standard has not come into force yet, however, it was prepared as a draft text.

The companies below are liable to implement the Turkish (TAS/TFRS) of IFRS (http://www.denetimnet.net/):

- Companies with share capital and their subsidiaries that are included in the scope of consolidation

- Public limited companies, intermediary institutions, portfolio management companies and the other business enterprises that are included in the scope of consolidation,

- Banks and their affiliated companies,

- Insurance and reinsurance companies,

- Individual pension companies,

By International Accounting Standards Board "IASB" the International Financial Reporting Standard (IFRS for SMEs) has been issued for the business enterprises who are staying out of the scope of TAS/TFRS and who do not have accountability to the Public and for small and mediumscaled business enterprises. This standard is a simplified form of a full set of IFRSs and it is formed by 35 chapters. Having the same system within the IFRSs that has been incorporated into our legislation as TAS/TFRS by de 
facto, has played a significant role regarding the adoption of the IFRS for SMEs by TASB. IFRS for SMEs was translated into Turkish word for word has been issued under the name of SME TFRS (http://www.behrendt.com.tr).

There are business enterprises who prepare General Purpose Financial Statements for foreign users such as Credit Rating Agencies. In addition to the above-mentioned business enterprises there are business enterprises, who preferred to apply TMS/TFRS however they want to turn back again to the SME/TFRS application. Both of the business enterprises mentioned above are liable to apply "TFRS provisions" that are particular to SMEs.

\section{Conclusion}

IFRS is the body of rules regarding the preparation and presentation of the Financial Statements, and it is being issued by the International Accounting Standards Board (IASB). In order for the IFRS to be implemented by all the countries, the progress is being made within the process of the reconciliation. Many countries all over the World, also the European Union have passed this process and Turkey has got the edge on by transforming to IFRS.

Currently, in Turkey, the dual system is being used as an accounting system. The first of those is the "General Communique on Accounting System Application" which was in operation for a long time and was issued by the Ministry of Finance on 26.12.1992; another is the TAS/TFRS which is the Turkish translation of IFRS that is effectuated. The studies regarding the TAS/TFRS are continuous, and they are updated if required and new ones are being issued.

In Turkey in accounting the legal framework that the companies have to follow is being regulated by Tax Procedure Law, the Accounting System that is based on the Uniform Chart of Accounts, and Turkish Commercial Code. In Turkey, the entry of IFRS brought into force the existing system Tax Procedure Law, the Accounting System that is based on the Uniform Chart of Accounts and together with the Turkish translation of IFRS (TAS/TFRS) the companies have the liability to implement the Turkish version of IFRS that is TAS/TFRS. Implementation of this dual system in Turkey could cause a lot of chaos.

Within TAS/TFRS the First Recognition and the Period-end closing procedures of the transactions and the activities were identified. During this Recognition process, it has benefited from the accounts that take place within the Uniform Accounting Plan that is in operation since 1994. Only at the end of the period regarding the formation of the financial statements according to the TAS/TFRS, a situation arises such as one company has two financial statements and this causes a problem regarding the addressing of the presentation of the statements regarding the distribution of the Profit. 
The distribution of the profits of the Companies bases on the Financial Statements that were prepared according to the TAS/TFRS regarding their transactions such as the merger. In cases of the discrepancy during the Court and Expert Examination, the decision is being upheld according to the Financial Statements that are organized according to the TAS/TFRS however the suitability of the Financial Statements that are the point in question only could be confirmed by the Book of Accounts. The determination of the ones that are non-conforming to the inventory and valuation provisions within the TAS/TFRS could only be carried out by means of the accounting records of the Companies.

The problems could disappear by ending the dual system regarding the Recognition in Turkey, by the Recognition of the records of the accounting events according to the TAS/TFRS by taking the Uniform Chart of Accounts that is based on the Uniform Accounting System which has been in operation for a long time into consideration, and by forming the Financial Statements according to the TAS/TFRS. In order to speed up this process first of all Restructuring of the Uniform Chart of Accounts that is forming the basis of accounting which is compatible with the TAS/TFRS constitutes the basis.

\section{References:}

1. Aysan, M., (2008). National Harmonization to the International Financial Reporting Standards: Turkey Example, 12. World Accounting Historians Congress, İstanbul, 44-53.

2. Chen, S., Zheng, S., Wang, Y., (2002), Evidence From China on Whether Harmonized Accounting Standards Harmonize Accounting Practices, Accounting Horizons, Vol:16, No:3, September 2002, 83197.

3. Fritz, S., Lammle, C., (2003). The International Harmonisation Process Accounting Standards, Linköping Universitiet, International Master Program Strategy and Culture, 3, Master Tez.

4. Gücenme, Gençoğlu, Ü., (2007). Turkish Accounting Standards and Implementation, Türkmen Kitabevi, İstanbul.

5. Gücenme, Gençoğlu, Ü., Özerhan, Y., Karabınar, S., (2013). Turkish Financial Reporting Standards, Sakarya University Continuous Education Applications and Research Centre, Sakarya.

6. Güney, S., Yiğiter, Ş, Y., Korkmaz, M., Ceylan, N., (2012). Regarding the European Union process, the End Point arrived at the Harmonization of Turkish Accounting Standards with the International Accounting Standards, Adiyaman University Institute of Social Sciences Journal, Sayı:10, 109-128.

7. Hoyle, J. B., Schaefer, T., Timothy, D., (2004). Advanced Accounting, Mc Gray Hill Company, Seventh Edition. 
8. Kaya, İ., (2003). FASB-IASB Agreement and Towards to the Global Financial Accounting Standards, Chamber of Independent Accountants and Financial Advisors of İstanbul (ISMMMO), Accounting Audit Symposium Communique, Issue: 6, 1-18.

9. Parlakkaya, R., (2004). International Conformity in Accounting and Accounting Accommodation Efforts in Turkey that is in European Union Process, Selçuk University Faculty of Economics and Administrative Sciences Social and Economic Researches Journal, Issue: 7, 119-139.

10. http://www.denetimnet.net/UserFiles/Documents/2011/Yeni_TTK_v e_UFRS_uyumlu_TMS_ye_gecis.pdf (Date accessed: 01.02.2017).

11. http://www.behrendt.com.tr/assets/oth/TMS-TFRS-DonusumununSirketler-Uzerindeki-Etkisi.pdf (Date accessed: 01.02.2017).

12. http://kgk.gov.tr/DynamicContentDetail/6538/TMS/TFRS-2017-Seti (Date accessed: 01.02.2017). 